УДК 7.071.1(092)

\title{
Eminent Leaders of Musical Art in the Krasnoyarsk Territory: Vladimir Aleksandrovich Averin
}

\author{
Irina V. Efimova* and Galina V. Baranova \\ Krasnoyarsk State Institute of Arts \\ 22 Lenin Str., Krasnoyarsk, 660049, Russia
}

Received 15.01.2017, received in revised form 07.08.2017, accepted 12.08.2017

Life and career development of an eminent leader of the Krasnoyarsk Territory, the honored artist of the Russian Federation Vladimir Alexandrovich Averin are studied in the article. The path of the propagandist-balalaika player, the teacher and the scientist-researcher's becoming in the field of music is in the center of attention. The materials of the interview with V.A. Averin are provided in the article. The performer's contribution into the cultural life of the Krasnoyarsk Territory and into the development of musical education specializing in balalaika in the territory of Eastern Siberia is analyzed. The results of pedagogical, educational and research activity are summed up.

Keywords: Vladimir Aleksandrovich Averin, folk instruments, music education, personality, propagandist.

The article is written with the support from the KSUI Krasnoyarsk Regional Fund for the Support of Scientific and Scientific-Technical Activity.

DOI: 10.17516/1997-1370-0124.

Research area: culturology, art criticism.

"I was not prevented from development...", with these words Vladimir Aleksandrovich Averin - a musician who reached great heights in his professional activity characterizes the dominant of his creative development.

$\mathrm{He}$, a native of the outback of Russia, born in a difficult, first year of the Second World War in the most ordinary family ${ }^{1}$, became a virtuoso balalaika player, a teacher and a scientistresearcher.

However, the Averins family was not quite ordinary - it was a musical family.
His father Aleksandr Ivanovich Averin played the violin by ear and could read sheet music; his elder brother Vladislav played the trumpet and the mandolin in amateur string and brass bands at club "Metallurg"; his middle brother Yury could play the accordion and harmonica. The younger brother Vladimir got the balalaika, which determined his future destiny.

The youngest son of the Averins got acquainted with the balalaika only when he was eleven. But his musical abilities were manifested much earlier. As a child, he liked to repeat the

(C) Siberian Federal University. All rights reserved

* Corresponding author E-mail address: acamus.cabinet@mail.ru 
melodies he liked, especially the ditties that he sang on his way home from school. This way was long, about one and a half kilometer, so that there was an opportunity to sing to his heart's content. For a seven-year-old boy his voice was the only available musical instrument and singing was his favorite activity.

But the love for the balalaika did not come immediately; although Vladimir Averin had already learned to select tunes of military songs by ear he did not know the musical notation. His attitude to this instrument changed in 1952 under the influence of an indelible impression of a wonderful cantilena performed on the balalaika ${ }^{2}$.

Playing the balalaika became almost the main thing in his life from 1955, when the elder brother brought the youngest to the team of amateur performances in club "Metallurg". The team at that time was headed by Aleksandr Sergeevich Bikenin, who had just graduated from Sverdlovsk Music School specialized in the accordion, and his teacher was T.N. Zaporozhets. "Since that time," argues Vladimir Aleksandrovich, "my real life, which very few people at school guessed about, began".

Due to Bikenin the team grew into an orchestra of Russian folk instruments; young musicians started mastering sheet music in order to learn their parts by notes. In the evenings they had regular rehearsals. For V. Averin Bikenin's orchestra became a good primary school, and his natural gift was enhanced by technical skill.

The first serious achievement of the young balalaika player was the victory won at the Creative Youth Contest in Sverdlovsk ${ }^{3}$ (1956) and marked with the first degree diploma. The chairman of the jury Vladimir Vasilievich Znamensky, the head of the instruments department, immediately invited the laureate to enter Sverdlovsk Music School. However, at that time this proposal was not taken seriously, the winner, who did not even have a seven-year music school behind him, considered himself to be not ready for studying at the music school.

The second invitation came in 1958 from the same V.V. Znamensky, when he came to club "Metallurg" to listen to the rehearsal of the orchestra and the performance of Averin himself. And this time the invitation was rejected as well, though for family reasons. It was necessary to earn a living and the amateur musician had to work as a mechanic at the local Novotrubnyi plant, while continuing to play in the orchestra. Soon, however, the conviction that the wrong way was chosen matured, and, having discussed the pressing issue with his relatives, Vladimir decided to follow his vocation and entered Sverdlovsk Music School named after P.I. Tchaikovsky to Nikolai Fedorovich Rozhin's class $^{4}$ where he started studying "a lot and with pleasure", sometimes 7-8 hours a day.

His professional development went so fast that the sophomore "left N.F. Rozhin's mastering and took the performance development into his own hands". In fact, the student quickly surpassed his teacher, and the teacher, with his pedagogical insight, "did not interfere into his disciple's independent studying", limiting himself to helping in the repertoire choice and planning.

Carried away by the ensemble performance in the amateur orchestra, in the first year of his studies Vladimir Averin with his classmate Volodia Chudinovskikh formed a duet and began performing with concerts from time to time. In the second year of study a duet with a guitarist Volodya Maslennikov was made, then a quintet that included Vasily Skiba (small domra), Valery Morozov (domra alto), Valery Volosnikov (button accordion), Vladimir Averin (balalaika prima) and Vyacheslav Kann (balalaika contrabass). The ensemble members "gathered at their free of studies time and rehearsed" and soon started giving concerts in school, hospitals, the House of Officers, the Palace of Culture named after 
Gorky and even in the philharmonic hall; some programmes were recorded on the radio and included in TV programmes.

Concert successes did not remain unnoticed, and in the summer of 1962, the students-ensemble players were included in the Philharmonic Brigade for servicing the Pioneer camps in the Sverdlovsk Region. The brigade included a reader Victor Petrovich Tretyakov (who was also a presenter), a tenor Nikolai Ivanovich Chernyavsky, a singer Gurovskaya, an accordion player Anatoly Yakovlevich Trofimov and the duet. Philharmonic work was well paid for those times, and for the money earned V.A. Averin bought a good balalaika and a concert suit. This came in handy: a participation in the $3^{\text {rd }}$ AllRussian Competition of Variety Performers in Moscow was expected.

Ensemble playing in many ways contributed to the development of technical equipment, necessary for solo performance. Even in the student years, extensive concert practice developed "immunity" against a dangerous for any performer "virus" - stage fright and fear of publicity. All this, taken together, stimulated the process of the performing musician's artistic personality formation.

In the years of study at the school (to be more precise during in the fourth year of study), he also started pedagogical activity. Vladimir Averin recalls: "Pedagogics became a revelation for me". It encouraged the beginning teacher to observe the work of their teachers, to analyze their experience. Gradually he started forming his own methodological techniques.

Thus, by the end of his studies at the school, V. Averin already appeared in three roles: a balalaika soloist, an ensemble player and a teacher. With such a background he easily (after performing only one play) entered Sverdlovsk Conservatory, where the Folk Instruments Department, which was headed by Rozhin's disciple Evgeny Grigorievich Blinov, was opened in 1963.

The years of training with Blinov (5 years at the conservatory and 2 years in the assistant internship) were fruitful not only professionally. The student was admitted to his teacher's home, they had friendly, trusting relationship. Everything was important in communication with an outstanding musician: how he dresses, how he talks, how he behaves and, of course, how he teaches. And classes with him "were a revelation and a celebration for the soul and body" - a revelation of the highest professional skills and a celebration of the gifted persons' affinity: both the teacher and the disciple were melodists.

The first significant result of the beneficial cooperation for the student was the first solo oneact concert that took place on 17 April 1967 in the Small Hall of Conservatory. A very complicated program was presented at the concert ${ }^{5}$.

The years in the conservatory were not only the time of study, but also the time of great concert practice. Thus, in one month of 1970 there were 42 concerts, and in 1968 there were tours in Japan ${ }^{6}$. At the same time, there was also pedagogical work at the school, where Averin replaced his teacher Rozhin.

A new stage of creative self-development began after finishing the assistantship V.A. Averin got job placement to Astrakhan State Conservatory, where he worked from 1971 to 1977 . The beginning university teacher, along with the special class of balalaika and domra, was immediately entrusted to conduct classes in pedagogics and methodology. Teaching at the university was supplemented by teaching at Astrakhan Music School - the lectures on methodology and classes of conducting. The colossal academic load did not prevent, however, neither daily 2-3 hours' classes on the favorite instrument, nor intensive concert work, 
performances on television or making adaptations of many compositions for the balalaika that replenished not too extensive balalaika repertoire.

Complex works were crowned in 1972 with the deserved success - a victory at the $1^{\text {st }}$ AllRussian Competition of the Folk Instruments Performers in Moscow, where Vladimir Alexandrovich was awarded with the title of the second prize laureate.

The next and, perhaps, the most fruitful stage of the musician's career was connected with Krasnoyarsk. "In the newspaper "Sovetskaya Kultura" ("Soviet Culture") I read an announcement about the opening of the Institute of Arts in Krasnoyarsk", recalls Vladimir Aleksandrovich, "and soon received an offer to head the Chair of Folk Instruments at the new university".

He had to work hard at the only Institute of Arts in Eastern Siberia. Already in the first year of work (1978), it was necessary to ensure the students admission, including within the admissions committee and also to take over the position of pro-rector for academic and scientific work of the Institute ${ }^{7}$. In fact, he had to start all this work from scratch. It was necessary to develop a form of class register ${ }^{8}$, a freshman's workbook (which included the contacts of professors, opening hours of the library and even the approximate schedule of the student's day), and establish methodological links between the Institute and the musical educational institutions (schools and colleges) of Eastern Siberia.

Administrative duties "devoured" a lot of precious time. But Averin managed to combine them with the performance activity. The concerts were both solo and cathedral. The solo concert with the Student Russian Orchestra in the Small Concert Hall of the Krasnoyarsk Philharmonic Hall (1994) was especially remembered. The programme of this concert was made with the expectation, as A. Averin puts it, "to show the balalaika not as a lightweight, entertaining instrument, but as an instrument with its original repertoire".

The geography of concert performances covered almost all the settlements of the Krasnoyarsk Territory. But the tours were not limited by the Krasnoyarsk Territory: Averin went abroad twice - to Germany (in 1988) with a creative team from the Krasnoyarsk Territory in a duet with the button accordion player Efim Jourist and to the USA (in 1990), where solo performances and duets with the button accordion player Nikolai Shul'pecov took place. He was also engaged in musical enlightenment. Averin, in particular initiated a series of TV programs that took place in the format of interviews with famous Russian musicians (1984-1985): "Five Years to the KSIA", "Plays the Laureate of the All-Union and International Competitions Sergey Naiko", "We Have a Visit from Boris Feoktistov, "The Domra Duet" and "Meet Vladimir Kozlov".

These conversations initiated scientific research. Averin was mostly interested in the history of performing with folk instruments (balalaikasinparticular)inSiberia.Butthisinterest required a long and diligent work in the archives. Its first result was a methodological research "Musical Instruments in the Life of Russian People (Methodological Recommendations in Support for the Lecturer, Propagandist, Speaker and Lecturer of the People's University)". The textbook included historical documents about Russian folk instruments found in archives, the role of instruments in the everyday life of Russian people in the $17^{\text {th }}-19^{\text {th }}$ centuries, about the skomorokhs - the masters of playing these instruments, about V.V. Andreev - a famous founder of the Great Russian Orchestra, about the professional art of playing the folk instruments at the present time.

This publication was only a touchstone. After that more than a dozen works on the same 
topic followed: "The Folk Talents. From the History of Playing the Russian Folk Instruments in the Krasnoyarsk Territory" (1998), "Russian Renaissance in Siberia: From the History of Playing the Russian Folk Instruments in the Krasnoyarsk Territory" (1989), "At the Origins of the Russian Folk Instruments Professional Performance in the Yenisei Province" (1991), "The First Siberian Great Russian Orchestra and its Place in the Musical Culture of the Yenisei Province" (1992), "Russian Folk Instruments in the System of Music Education in the Krasnoyarsk Territory (19201930s)" (1993), "Russian Folk Instruments and Music Education in the Krasnoyarsk Territory (40-60s)" (1997), "Instrumental Folk Music in Krasnoyarsk from the Middle of the $17^{\text {th }}$ to the Early $20^{\text {th }}$ Century" (2009), etc.

Along with the historical issue, methodological issue was topical as well. V. Averin, in particular, was concentrated on the issue of the unity of the performer's interpretation of the soloist and accompanist: experience demonstrated that there was a lot of disagreement on this field. This is how "The Work with the Accompanist in the Class of Plucked Instruments" (1982) appeared; its leitmotif was "the timid attitude of the teacher in the specialty to the accompaniment, when all the attention in the lesson is transferred only to the student or the teacher naively puts the entire accompanist's work on the concertmaster's shoulders". Opposed to it, ideas, tested during his own pedagogical practice were put forward: "There is an opinion that the accompaniment should sound quieter than the solo party. For the sake of this, some teachers tend to remove the sound of the piano, and above all, with the help of the left pedal. ... If you remove the piano sonority, for example, in the "Spanish Dance" by de Falla (especially after the second theme), the polyphonic language of the piece might be impaired. Do not hide the part of the piano, but play brighter, creating thereby together with the soloist a relief multilayered fabric - one of the main goals of the teacher's work with the accompanist".

The textbook "Working with the Accompanist" was mainly addressed to the beginning teachers of music schools for children and art colleges, but the ideas outlined in turned out to be also in demand in the higher educational institution. The issue of "soloist - accompanist" was developed into a number of textbooks: "Working with a Student in a Specialized Class" (1987), "Advice to a Young Domra Player" (1988), "Topical Issues of Modern Instrumental Folk Pedagogy" (1995), "On the Performing Balalaika Techniques and Strokes" (1981), “Classics in the Balalaika Performance: Examples of Interpretation" (2012).

Particular attention was paid to the problem of the repertoire, since little was written for the balalaika. It was possible to fill the gaps cooperating with Krasnoyarsk composers. In this way another direction in Vladimir Aleksandrovich's work appeared. A lot has been done in this field. In particular, a whole series of collections has been published. These were "Ancient Sonatas in the Adaptations for the Balalaika and the Piano" (1999), which included Sonatas No. 3, 7, 8, 9 by D. Cimarosa, Sonata No. 1 (Overture), No. 3 (Largo and Rondo), No. 6 by F. Verachini, Sonata No. 4 (Prelude, Courante, Gigue) by A. Vivaldi; “Concert Pieces for the Balalaika and the Piano from Vladimir Averin's Repertoire" (Saraband and Allegro by J.S. Bach, Variations on a Theme by Handel by A. Sapalov, Paraphrase on a Theme of "Elegy" by M. Yakovlev by V. Ryabov, Theme and Variations on a Theme of Japanese Folk Songs "Sakura" for balalaika solo by Y. Yōk̄ō, "Heavenly Waltz" by R. Dyens, "Verano Portena" (Tango), "Primavera" "Porteno" (Tango) by A. Piazzolla. These and many other works sounded in Vladimir Aleksandrovich's concert programme. 
With all the diversity of activities, only pedagogy remained unchanged, at that not only in the specialized class, but also in such disciplines as: conducting, prima vista, methodology and ensemble. For some time he had to head the Chair of Folk Instruments: its teaching staff was heterogeneous, specialists came with their styles, methods and their views on the educational process. All this had to be brought to a single methodological "denominator", so that the department would become a wellcoordinated ensemble, rather than a bunch of randomly converging specialists. And yet the main concern was the specialized class, where each student had his own identity, potential, talent and physiological characteristics, where each student needed a special approach. And there the principle, inherited from the teachers: to teach without interfering; not hurting the personal identity of young talents, without losing the main perspective: "to train not only soloists, but also professional teachers" turned out to be very appropriate.

This pedagogical strategy bore its fruit. A brilliant pleiade of musicians-performers and teachers, who were in demand not only in Russia, but also abroad came from V. Averin' class. These were 76 graduates-laureates, 9 assistants and post-graduate students. And almost all the students regularly corresponded with their teacher, sharing their pressing problems and invariably receiving support in all their life and creative situations ${ }^{9}$. The extensive list of students includes honored workers of culture of the Russian Federation (Z.V. Abikh-Guba, N.Yu. Zamyatin, V.N. Serdyuk), laureates and award winners of international competitions (K.V. Mironov, E.R. Starodumov, A.N. Shakorin, V.A. Makarova, P.A. Svetashkov, M.Yu. Kirillov, D.V. Borovkov， O.M. Karataev， S.G. Rymar', A.S. Zayats-Kuznetsova, D.G. Lashkin and T.V. Paramonova).

Having prepared an entire army of teachers and performers, V. Averin not only created the Krasnoyarsk balalaika performance school, providing Eastern Siberia with the first-class musicians, but also passed them the torch of the propaganda for the instrument with which he himself went side-by-side almost all his life.

Multifaceted creative work of the Teacher payed off in spades. The creative successes of the students, their love and trust are the most precious gift for the Teacher and, at the same time, the most reliable evidence of his skill, that cannot be measured by any competition ratings.

V.A. Averin was born on 29 August 1941 in Nitsitsky state farm of Slobodo-Turinsky district of the Sverdlovsk region. His mother was a postal worker and his father was a duty technician at a telephone exchange.

2 As it turned out later, it was the theme of the second part of the Concerto No. 1 by Evgenii Pavlovich Kichanov, a Ural composer, performed by Nikolai Fedorovich Rozhe, a teacher at Sverdlovsk Music School named after P.I. Tchaikovsky.

In the duet with an accordionist, "The Moon Shining" and "Eh, Nastasya" by A. Dobrokhotov were performed.

4 According to V.A. Averin memoirs, "Nikolai Fedorovich Rozhin is a balalaika player of a native natural gift. Working as an assistant train driver, he independently mastered the tool, and then did the full course of the musical school where he was taught by V.V. Znamensky. For the participation in 1939 All-Union Competition of Folk Instruments Players he was awarded a certificate of honour. N.F. Rozhin worked for several years as a soloist in Sverdlovsk radio committee and, in the ensemble of folk instruments under the direction of V. Znamensky. He had tenacious fluency, a rather deep tremolo. His "double pinch" (pizzicato with the thumb and index finger), at which the sound was extracted only due to the flexion and extension of fingers, without the involvement of the hand and forearm sounded especially good. It should be noted that Nikolai Fedorovich's right hand was muscular and his handshake was strong. Stocky, stout, with crewcut always wearing a tie, at first he looked a stern and strict man. But in fact, Nikolai Fedorovich turned out to be a kind and sympathetic person".

5 G. Handel's Passacaglia, the Concerto in three parts by N. Shulman, "Sad Waltz" by J. Sibelius, N. Puzei’s Sonata, Balalaika Waltz by V. Andreev and "Russian Tunes" by N. Rizol'.

${ }_{6}$ In 1968, V. Averin participated in the 2nd Festival of Friendship between Soviet and Japanese Youth in a duet with the button accordion player Mikhail Zhmur and a pop quartet from Arkhangelsk. 
7 V.A. Averin worked in the position of pro-rector from 1981 to 1988; after that, the "reins of government" were handed over to I.V. Efimova (pro-rector for scientific and creative work) and to K.A. Yakobson (pro-rector for academic work). It should be noted that in the post of pro-rector Averin had to manage all three directions of the Institute's activity simultaneously.

8 It is valid till the present day.

9 The archives of the museum of the Krasnoyarsk State Institute of Arts store a thick folder with this correspondence, handed over by V.A. Averin as a gift.

\title{
References
}

Averin, V.A. (2008). Gordoe imia - narodnik [The Proud Name - Populist]. Krasnoyarsk, 154 p. Averin, V.A. (1983). Muzykal'nye instrumenty v zhizni russkogo naroda (Metodicheskie rekomendatsii v pomoshch lektoru, propagandistu, dokladchiku i prepodavateliu narodnogo universiteta) [Musical Instruments in the Life of Russian People (Methodological Recommendations in Support for the Lecturer, Propagandist, Speaker and Lecturer of the People's University]. Krasnoyarsk, 19 p.

Averin, V.A. (1982). Rabota s kontsertmeisterom v klasse shchipkovykh instrumentov [The Work with the Accompanist in the Class of Plucked Instruments]. Krasnoyarsk, 16 p.

Belik, P.A. (1994). 25-letie kafedry narodnykh instrumentov Astrakhanskoi gosudarstvenno konservatorii [25 $5^{\text {th }}$ Anniversary of the Chair of Folk Instruments in Astrakhan State Conservatory], In Narodnik, 2, 34-35.

Bibergan, V. (2003). Kompozitor Vadim Bibergan rasskazyvaet [Composer Vadim Bibergan Narrates], In Narodnik, 3 (43),14.

Gorbachev, A. (2003). Uchebnik po istorii ispolnitel'stva V. Averina [Textbook on the History of Artistic Performance], In Narodnik, 3 (43), 44-45.

\section{Выдающиеся деятели музыкального искусства в Красноярском крае:}

\section{Владимир Александрович Аверин}

\author{
И.В. Ефимова, Г.В. Баранова \\ Красноярский государственный институт искусств \\ Россия, 660049, Красноярск, ул. Ленина, 22
}

\begin{abstract}
В статье рассматривается жизненный и творческий путь выдающегося деятеля Красноярского края, заслуженного артиста РФ - Владимира Александровича Аверина. В центре внимания - путь становления пропагандиста-балалаечника, педагога, ученого-исследователя на музыкальном поприще. В статье представлены материаль интервью с В.А. Авериным. Анализируется вклад артиста в культурную жизнь Красноярского края, в развитие музыкального образования по классу балалайки на территории Восточной Сибири. Подводятся итоги педагогической, просветительской, исследовательской деятельности.
\end{abstract}

Ключевые слова: Владимир Александрович Аверин, народные инструменты, музыкальное образование, личность, пропагандист.

Статья написана при поддержке Красноярского регионального фонда поддержки научной и научно-технической деятельности КГУИ.

Научная специальность: 24.00.00 - культурология, 17.00.00-искусствоведение. 